\title{
PERFUSION OF MALIGNANT HYPERTHERMIA SUSCEPTIBLE AND NORMAL ISOLATED PIG LIVERS WITH HALOTHANE
}

\author{
Beverley A. Britt, Barry Shandling, Laszlo Endreny, and Geraldine M. Kent
}

THE DEFECT of malignant hyperthermia (MH) may be widespread involving many membranes of many tissues. ${ }^{1.2}$ Thus, Berman's report ${ }^{3}$ that liver temperatures rise faster and higher than skeletal muscle temperatures in Landrace pigs during malignant hyperthermia reactions and Brucker's finding 4 of degeneration of the liver endoplasmic reticulum during malignant hyperthermia crises in Poland-China pigs hint that a primary abnormality may exist in the livers of malignant hyperthermia susceptible swine. Since the liver, ${ }^{5}$ unlike the skeletal muscle, ${ }^{6-10}$ does not contain triads (transverse tubules plus sarcoplasmic reticulum) the presence of a primary derangement in the liver would indicate that the site of the muscle defect is not in any of the components of the triads.

We have, therefore, perfused isolated pig livers with blood containing halothane. Before, during and after perfusion, several parameters (temperature, blood gases, serum enzymes, serum electrolytes and blood glucose, lactate and pyruvate) which are known to change during malignant hyperthermia reactions have been measured.

\section{METHODS}

\section{Selection of MHS and Normal Pigs}

The malignant hyperthermic susceptible swine were either purebred Poland-China or crossbred Poland-China/York pigs. They were all descendants of two purebred malignant hyperthermia

Beverley A. Britt, M.D., F.R.C.P.(C), Associate Professor, Department of Anaesthesia, University of Toronto and Assistant Professor, Department of Pharmacology, University of Toronto; Senior Staff Anaesthetist, Toronto General Hospital, Toronto, Canada.

Barry Shandling, M.B. Ch.B., F.R.C.S.(Eng), F.R.C.S.(C), F.A.C.S., Assistant Professor, Department of Surgery, University of Toronto; Staff Surgeon, Hospital for Sick Children, Toronto, Canada.

Laszlo Endrenyi, Ph.D., Professor, Department of Pharmacology, University of Toronto and Associate Professor, Department of Preventive Medicine and Biostatistics, University of Toronto, Toronto, Canada.

Geraldine M. Kent, D.V.M., M.Sc., Research Associate, Research Institute, Hospital for Sick Children, Toronto, Canada. susceptible Poland-China pigs obtained from the colony maintained by Jones and Nelson at Oklahoma State University. " The normal pigs were York hogs or purebred Poland-China pigs. The malignant hyperthermia status of the pigs was determined by in vivo halothane challenge and the caffeine contracture test. ${ }^{12,13}$ Pigs which developed tachycardia, rigidity and fever following halothane inhalation and whose skeletal muscle fascicles in vitro required less than $9.0 \mathrm{mmol}$ of caffeine to develop more than 1.0 gram increase in resting tension were considered to be malignant hyperthermia susceptible. On the other hand, pigs which did not respond adversely to halothane in vivo, and whose skeletal muscle fascicles in vitro required more than $9.0 \mathrm{mmol}$ of caffeine to develop more than 1.0 gram increase in resting tension were deemed to be normal.

\section{Anaestheric and Surgical Techniques}

Anaesthesia consisted of thiopentone by the intravenous route and nitrous oxide and oxygen through a tracheal tube. The animals were ventilated with an Air Shields ventilator. Bypasses were inserted between the portal vein and left external jugular vein, and between the inferior vena cava and right external jugular vein. The hepatic artery and the supra-hepatic inferior vena cava were clamped. The severed ends of the portal vein and inferior vena cava proximal to the liver were connected to a Bentley pump oxygenator. The oxygenator was primed with heparinized blood containing sodium bicarbonate. In a pilot study, the effect of the addition of glucose and/or calcium to the priming fluid was examined. As their presence did not substantially alter the results, they were omitted from the priming fluid in the reported study. Enough carbon dioxide was added to the priming fluid to keep its $\mathrm{PCO}_{2}$ within the normal range. Temperature probes were inserted between the lobes of the liver. Samples of the blood entering and leaving the liver were obtained for measurement of blood gases $\left(\mathrm{Pa}_{\mathrm{O}_{2}}, \mathrm{~Pa}_{\mathrm{CO}_{2}}, \mathrm{pH}, \mathrm{BE}\right)$, lactate and pyruvate. One and one half per cent halothane was then administered to the liver in the pump perfusion fluid for one hour. During this period of 
TABLE I

Pig Temperatures and Heart Rate at beginning of anaesthesia

\begin{tabular}{lcccccc}
\hline & & $\begin{array}{c}\text { Nasal } \\
\text { temperature } \\
{ }^{\circ} \mathrm{C}\end{array}$ & $\begin{array}{c}\text { Skin } \\
\text { temperature } \\
{ }^{\circ} \mathrm{C}\end{array}$ & $\begin{array}{c}\text { Muscle } \\
\text { temperature } \\
{ }^{\circ} \mathrm{C}\end{array}$ & $\begin{array}{c}\text { Rectal } \\
\text { temperature } \\
{ }^{\circ} \mathrm{C}\end{array}$ & $\begin{array}{c}\text { Heart rate } \\
\text { per } \\
\text { minute }\end{array}$ \\
\hline Control & $\bar{\chi}$ & 38.27 & 36.77 & 39.66 & 38.45 & 146.3 \\
MHS & S.E. & $(0.35)$ & $(1.02)$ & $(0.23)$ & $(0.51)$ & $(10.9)$ \\
& $\bar{\chi}$ & 38.74 & 37.30 & 39.77 & 38.94 & 137.7 \\
t-test & S.E. & $(0.42)$ & $(0.65)$ & $(0.27)$ & $(0.38)$ & $(6.7)$ \\
Degrees of freedom & & -0.86 & -0.42 & -0.30 & -0.75 & -0.62 \\
& & 13 & 13 & 13 & 13 & 12 \\
\hline
\end{tabular}

perfusion with halothane, serial samples of blood entering and leaving the liver were withdrawn every 15 minutes for repeat measurements of the above blood parameters. At the end of the onehour equilibration final blood specimens were obtained and the animal was sacrificed.

The livers of eight normal and seven malignant hyperthermia susceptible swine were perfused.

\section{Results}

The results are shown in Tables I to VI. Statistical analysis shows that there are no substantial differences between livers of the MHS and the normal animals. In neither group of animals does halothane induce a rise in liver temperature (Table II). In the perfusing blood both entering and leaving the liver percentage changes of oxygen, carbon dioxide, base deficit and lactic acid are also similar in the two groups (Tables III-VI).

\section{Discussion}

The results show that the primary defect of malignant hyperthermia does not appear to involve the liver adversely.

It has been postulated that the primary defect of malignant hyperthermia involves the sarcoplasmic reticulum of the skeletal muscle. A latent impairment of uptake into, binding to or acceleration of release of calcium from the sarcoplasm reticulum may be activated by triggering drugs such as halothane. Some evidence suggests that malignant hyperthermia involves tissues other than skeletal muscle, for example, heart muscle $e^{14-16}$, bone $\mathrm{e}^{17-19}$ and platelets $\mathrm{s}^{20-24}$. This is not surprising since the normal functioning of these cell types is dependent on rapid redistribution of intracellular calcium. A defect in the liver would be less expected since, so far as is known, liver cells do not depend for most of their normal
TABLE II

Pig Temperatures Before and after Halothane Challenge

\begin{tabular}{|c|c|c|}
\hline & \multicolumn{2}{|c|}{ Liver } \\
\hline & $\begin{array}{l}\text { Pre }^{*} \\
{ }^{\circ} \mathrm{C}\end{array}$ & $\begin{array}{l}\text { Post } \dagger \\
{ }^{\circ} \mathrm{C}\end{array}$ \\
\hline $\begin{array}{l}\text { Control } \\
\text { (SE) }\end{array}$ & $\begin{array}{l}37.0 \\
\quad(0.54)\end{array}$ & $\begin{array}{l}36.89 \\
\quad(0.39)\end{array}$ \\
\hline $\begin{array}{c}\text { MHS } \\
\text { (SE) }\end{array}$ & $\begin{array}{l}37.67 \\
\quad(0.38)\end{array}$ & $\begin{array}{l}37.73 \\
\quad(0.45)\end{array}$ \\
\hline$t$ & -0.99 & -1.41 \\
\hline $\mathrm{df}$ & 13 & 13 \\
\hline
\end{tabular}

*Pre = value obtained from arterial blood entering liver immediately before commencement of halothane perfusion.

$\dagger$ Post $=$ value obtained from venous blood leaving liver immediately after completion of halothane perfusion.

functions on rapid redistribution of free intracellular calcium between the cytoplasm and structures functionally analogous to the sarcoplasmic reticulum. The endoplasmic reticulum of the liver, while similar in nomenclature and histological appearance to the skeletal muscle sarcoplasmic reticulum, nevertheless are functionally different from it. For instance, the rough endoplasmic reticulum of the liver manufactures proteins and the smooth endoplasmic reticulum of the liver catabolizes drugs and waste products of metabolism. So far as is known, cyclical binding of calcium is not a function of these liver organelles. Rather, liver functions such as phosphorylaseb-kinase activated glycolysis are mediated by calcium taken up from the extracellular fluid ${ }^{25,26}$, or by calcium redistributed between the cytoplasm and the mitochondria. ${ }^{27-29}$

Other postulations for the defect of malignant hyperthermia include excessive permeability of the cell membrane to extracellular fluid calcium; 


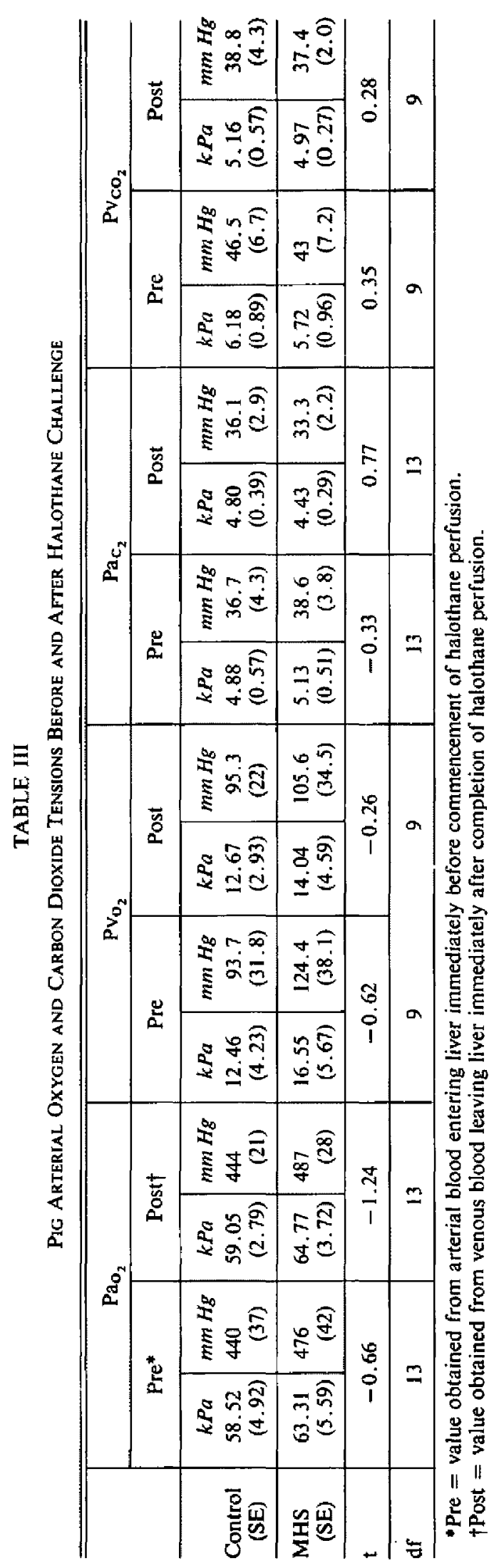


TABLE IV

Pig Base Deficits and Blood Lactate Before and After Halothane Challenge

\begin{tabular}{|c|c|c|c|c|c|c|c|c|}
\hline & \multicolumn{2}{|c|}{$\begin{array}{l}\text { Arterial } \\
\text { lactate } \\
\mathrm{mmol} / 1\end{array}$} & \multicolumn{2}{|c|}{$\begin{array}{l}\text { Venous } \\
\text { lactate } \\
\text { mmol/1 }\end{array}$} & \multicolumn{2}{|c|}{$\begin{array}{l}\text { Arterial } \\
\text { base deficit } \\
\mathrm{mmol} / \mathrm{l}\end{array}$} & \multicolumn{2}{|c|}{$\begin{array}{l}\text { Venous } \\
\text { base deficit } \\
\text { mmol/l }\end{array}$} \\
\hline & Pre & Post & Pre & Post & Pre & Post & Pre & Post \\
\hline $\begin{array}{c}\text { Control } \\
\text { (SE) }\end{array}$ & $\begin{array}{l}9.8 \\
(1.6)\end{array}$ & $\begin{array}{l}6.2 \\
(1.5)\end{array}$ & $\begin{array}{c}10.0 \\
(1.8)\end{array}$ & $\begin{array}{l}6.5 \\
(1.8)\end{array}$ & -1.2 & $\begin{array}{l}2.1 \\
(4,9)\end{array}$ & $\begin{array}{l}0.6 \\
(6.2)\end{array}$ & $\begin{array}{l}1.9 \\
(6.0)\end{array}$ \\
\hline $\begin{array}{l}\text { MHS } \\
\text { (SE) }\end{array}$ & $\begin{array}{l}13.8 \\
\quad(2.7)\end{array}$ & $\begin{array}{l}8.0 \\
(1.5)\end{array}$ & $\begin{array}{l}13.7 \\
(2.3)\end{array}$ & $\begin{array}{l}7.5 \\
(1.5)\end{array}$ & -1.2 & $\begin{array}{r}-1.7 \\
\quad(1.8)\end{array}$ & $\begin{array}{r}-2.9 \\
\quad(3.3)\end{array}$ & -1.1 \\
\hline$t$ & -1.29 & -0.86 & -1.28 & -0.39 & 0.01 & 0.69 & 0.47 & 0.44 \\
\hline df & 13 & 13 & 13 & 13 & 13 & 13 & 9 & 9 \\
\hline
\end{tabular}

or decreased ability of the cell membrane to bind calcium; ${ }^{30-34}$ or reduced uptake into or binding in or increased release of calcium from mitochondria. ${ }^{35.36}$ The absence of any evidence of reaction in malignant hyperthermia susceptible livers perfused with halothane does not provide support for any of these proposals. It may be, however, that because of different genetic control and, therefore, different structural and functional qualities, a defect in malignant hyperthermia susceptible skeletal muscle mitochondria or sarcolemma is not necessarily also present in malignant hyperthermia susceptible liver mitochondria or liver cell membranes.

Clinical evidence suggests that in malignant hyperthermia susceptible humans the liver is inherently normal. Thus Denborough ${ }^{37}$ and others $^{38.39}$ have reported that acute malignant hyperthermia reactions in man are associated with, and followed by, normal or almost normal liver function tests. Reductions in liver function which occasionally have been observed during malignant hyperthermia reactions are sufficiently minor that they can be considered to be secondary to haemodynamic and biochemical derangements originating extraneous to the liver. The findings in our normal and malignant hyperthermia susceptible pigs confirm the previous observations in susceptible humans. ${ }^{37-39}$

Since the changes induced by perfusion of isolated malignant hyperthermia susceptible pig livers with halothane are not different from those observed in normal pig livers similarly perfused, we must conclude that a primary defect of malignant hyperthermia probably is not located in the liver - an organ devoid of organelles functionally similar to the sarcoplasmic reticulum of the muscle. This study also supports, but does not confirm the postulation that the malignant hyper- thermia defect of muscle includes a defective sarcoplasmic reticulum membrane and does not support, but does not rule out, a defect in the mitochondria.

\section{SUMMARY}

We have perfused malignant hyperthermia susceptible and normal isolated pig livers with halothane for one hour. The liver temperatures, oxygen and carbon dioxide tensions, the base deficits and lactate concentrations in blood entering and leaving the liver have been measured at the beginning and at the end of the perfusion. Statistical analysis has shown that there are no significant differences in these parameters between the beginning and the end of the perfusion period or between the normal and the malignant hyperthermia susceptible livers. We conclude, therefore, that the livers of malignant hyperthermia susceptible pigs are either normal or else. if abnormal, the abnormalities are sufficiently benign as to be not measurably expressed.

\section{RÉSUMÉ}

Des foies isolés de porcs susceptibles à l'hyperthermie maligne ont été perfusés à l'halothane pendant une heure. Les températures du foie, les tensions de l'oxygène et du gaz carbonique, le déficit en bases, et la corcentration de lactate ont été mesurés dans le sang en amont et en aval de l'organe au début et à la fin de la perfusion. L'analyse statistique n'a pas révélé de différence significative dans ces paramètres entre le début et la fin de la perfusion ou entre les foies normaux et les foies susceptibles à l'hyperthermie maligne. De là, nous concluons que le foie du porc susceptible à l'hyperthermie maligne est possiblement 

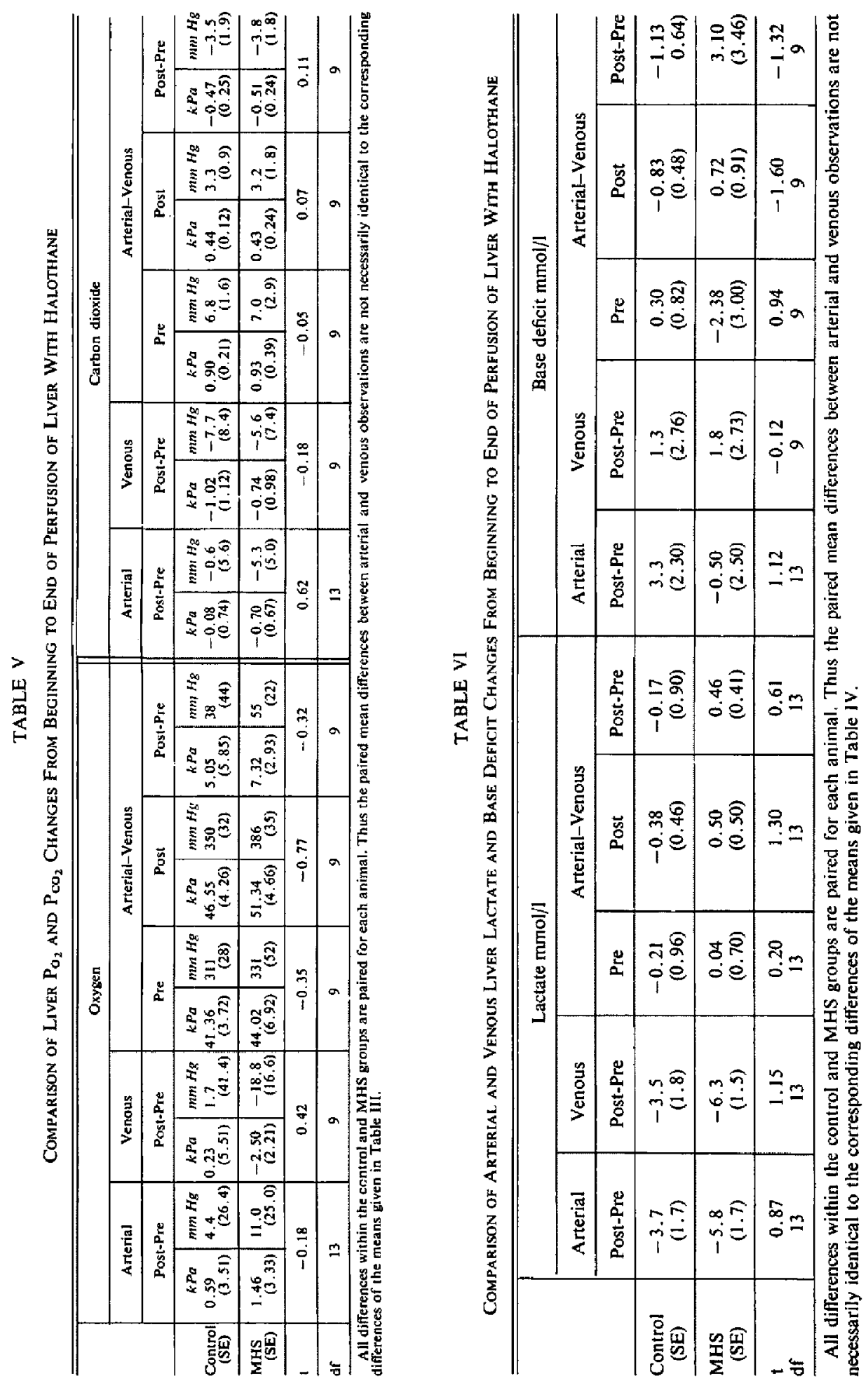
normal. S'il ne l'est pas, cette anomalie pourrait-être telle qu'on ne puisse la quantifier.

\section{ACKNOWLEDGEMENTS}

This work was supported by a grant from the Medical Research Council of Canada.

The authors wish to thank Mr. S.F.H. Moosavi for his assistance in the preparation of the calculations for this work.

\section{REFERENCES}

1. BRI7T, B.A. Malignant hyperthermia - 1977. In: Complications in Anesthe siology (eds. Orkin, F.K. and Cooperman, L.H.), J.B. Lippincott Co., Philadelphia, Pa. In press (1977).

2. BRITT, B.A. Malignant hyperthermia - aetiology and pathophysiology. In: Anaesthesiology, Proceedings of the VI World Congress of Anaesthesiology, Mexico City, April 24-30, 1976. Ed. Husxz, E. and Lunn, J.N. Excerpta Medica, Amsterdam-Oxford (1977).

3. Berman, M.C. \& Kench, J.E. Biochemical features of malignant hyperthermia in Landrace pigs. In: International Symposium on Malignant Hyperthermia (ed. Gordon, Britt, Kalow), Charles C. Thomas, Springfield, p. 287 (1973).

4. Brucker, R.F., Williams, C.H., Popinigis, J., Galvez, T.L., Vall, W.J., \& TAYLoR, C.A. In vitro studies on liver mitochondria and skeletal muscle sarcoplasmic reticulum fragments isolated from hyperpyrexic swine. In: International Symposium on Malignant Hyperthermia (ed. Gordon, Britt, Kalow), Charles C. Thomas, Springfield, p. 238(1973).

5. Rouiller, Ch. (ed.) The Liver - Morphology, Biochemistry, Physiology. Volumes I and II. Academic Press, N.Y. (1963)

6. Sandow, A. Skeletal muscle. Ann. Rev. Physiol. $32: 1040$ (1970).

7. HoYle, G. How is muscle turned on and off? Sci. Am. 222: 85 (1970).

8. Hasselbach, W. Relaxing factor and the relaxation of muscle. Progress in Biophysics 14: I (1964).

9. HUXLEY, H.E. Structural evidence concerning the mechanism of contraction in striated muscle. $I n$ : Muscle (ed. Paul, W.M., Daniel, E.E., Kay, C.M., and Monckton, G.), Pergamon Press, Oxford (1965).

10. Porter, K.R. \& Franzini-Armstrong. C. The sarcoplasmic reticulum. Sci. Am. $2 / 2: 73$ (1965)

11. Jones, E.W. \& Nelson, T.E. Personal communication. Oklahoma State University, Stillwater, Oklahoma.

12. Britt, B.A., Kalow, W., Gordon, A., HumPHREY, J.G., \& RewCAstle, N.B. Malignant hyperthermia - an investigation of five patients. Canad. Anaesth. Soc. J. 20: 431 (1973).

13. Britt, B.A., Endrenyi, L., Kalow, W., \& PETERS, P.L. The adenosine triphosphate (ATP) depletion test: comparison with the caffeine contracture test as a method of diagnosing malignant hyperthermia susceptibility. Canad. Anaesth. Soc. J. $23: 624$ (1976)
14. Huckell, V.F., Staniloff, H.M., MclaughLiN, P.R., BritT, B.A., \& MoRCh, J.E. Cardiovascular manifestations of normothermic malignant hyperthermia. Presented at the 2nd International Symposium on Malignant Hyperthermia, Denver, Colo., April 1-3, 1977.

15. Huckell, V.F., Staniloff, H.M., Britt, B.A., Waxman, M.B., Feiglin, D.H., Mclaughlin, P.R., \& MORCH, J.E. Thallium-201 myocardial jmaging in malignant hyperthermia: a membrane disease. Accepted for presentation at the American College of Cardiology, March 6-9, 1978, Anaheim. California.

16. Huckell, V., Staniloff, H., Britt, B.A., Feiglin, D., Mclaughlin, P., Waxman, M., \& MORCH, J. Cardiac abnormalities in malignant hyperthermia. Accepted for presentation at the 50th Scientific Sessions, American Heart Association, November 28-December 1, 1977, Miami, Fla.

17. Harrison, J.E. MCNeILl, K.G. Meema, H.E. Fenton, S., Oreopoulas, D.G., \& Sturtridge, W.C. Partial-body calcium measurements by in vivo neutron activation analysis: comparisons with $X$-ray photodensitometry measurements of the radius. J. Nucl. Med. 15: 929 (1974).

18. HARRISON, J.E. IVNAA experience with idiopathic osteoporosis and with osteoporosis secondary to hyperthyroidism and malignant hyperthermia. Presented at the 2nd Conference on In Vivo Neutron Activation Analysis, April 5-10, 1976, Glasgow, Scotland.

19. Harrison, J.E., Sturtridge, W.C., Williams, C. WATTS, J. \& McNeill, K.G. A bone calcium index based on partial body calcium measurements by in vivo activation analysis. J. Nucl. Med. 16: (1975).

20. Puszkin, E., Puszkin, S., Lo, L.W., \& TanenBAUM, S.W. Binding of cytochalasin D to platelet and muscle myosin. J. Biol. Chem. 248: 7754 (1973).

21. Johnson, S.A., van Horn, D.L., Pederson, H.J., \& MARR, J. The function of platelets: a review. Transfusion $6: 3(1966)$.

22. Puszkin, S.. Puszkin, E., Katz, A.M., \& ALEDORT, L. M. Control of platelet actomyosin activity: effect of $A D P$ on superprecipitation and ATPase activity of human platelet actomyosin. Biochim. Biophys. Acta 347; 102 (1974).

23. LeBowitz, E.A.\& COOKE, R. Contractile properties of myosin from human blood platelets. Circulation 56: Abstract \#284 (1977).

24. Puszkin, E.G., Spaet, T.H., Maimon, J., \& Puszkin, S. Platelet a-actinin: effect on actin properties. Circulation 56: Abstract \#285 (1977).

25. KePpens, S., VANDERHEede, J.R., \& DE WULF, $\mathrm{H}$. On the role of calcium as second messenger in liver for the hormonally induced activation of glycogen phosphorylase. Biochim. Biophys. Acta 496: 448 (1977).

26. FriedmanN, N. \& PARK, C.R. Early effects of 3',5'-adenosine monophosphate on the fluxes of calcium and potassium in the perfused liver of normal and adrenalectomized rats. Proc. Nat. Acad. Sci. 61: 504 (1968).

27. Lehninger, A.L. Mitochondria and calcium ion transport. Biochem. J. 119: 129 (1970).

28. Drahota, Z., Carafoli, E., Rossi, C.S., Gam* 
BLE, R.L., \& LEHNINGER, A.L. The steady state maintenance of accumulated $\mathrm{Ca}^{++}$in rat liver mitochondria. J. Biol, Chem. 240:2712 (1965).

29. BORLE, A.B. Cyclic AMP stimulation of calcium efflux from kidney, liver, and heart mitochondria. J. Membrane Biol. 16: 221 (1974).

30. Britt, B.A., Endrenyi, L., Peters, P.L. Kwong, F.H.-F., \& KadIJEVIC, L. Screening of malignant hyperthermic susceptible families by CPK measurement and other clinical investigations. Canad. Anaesth. Soc. J. 23: 263 (1976).

31. Mcintosh, D. \& Berman, M.C. Neutral lipid and phospholipid composition of normal and myopathic skeletal muscle of pigs. S. African Med. J. 48: 1221 (1974)

32. Moulds, R.F.W. \& Denborough, M.A Biochemical basis of malignant hyperpyrexia. Brit. Med. J. 2: 241 (1974).

33. NELSON, T.E., BEDELL, D.M., \& JONES, E.W Porcine malignant hyperthermia. Anesthesiology 42: 301 (1975).

34. Nelson, T.E., Jones, E.W., \& Holbert, D
Malignant hyperthermia: sarcolemmal defect? Unpublished manuscript.

35. Heffron, J.J.A., Theye, R.A., \& Gronert, G.A. Porcine malignant hyperthermia: calcium binding and release by isolated sarcoplasmic reticulum. Presented at the 2nd International Symposium on Malignant Hyperthermia, Denver, Colo., April 1-3, 1977

36. CheAh, K.S. \& CheAH, A.M. The trigger for PSE condition in stress susceptible animals. J. Sci. Fd. Agric. 27: 1137 (1976).

37. Denborough, M.A., Forster, J.F.A., Hudson, M.C., CarTer, N.G., \& ZaPf, P. Malignant hyperpyrexia - a serious, preventable complication of general anaesthesia. Australasian Congress of Anaesthesiology, Melbourne, Australia, 1970.

38. BRIrT, B.A. Unpublished data, 1977

39. Gordon, R.A., BrITt, B.A., \& Kalow, W. (eds.). International Symposium on Malignant Hyperthermia, Charles C. Thomas, Springfield (1973) 